\title{
The effectiveness of a nurse-delivered breast health promotion program on breast cancer early detection behaviors
}

\author{
Anita $^{1 *}$, Nelly Indrasari ${ }^{1}$, Purwati $^{1}$, Ratna Aryani ${ }^{2}$ \\ ${ }^{1}$ Keperawatan - Poltekkes Kemenkes Tanjungkarang-Bandar Lampung, Indonesia. \\ ${ }^{*}$ Corresponding author. E-mail: anitabustami@yahoo.co.id \\ 2Keperawatan - Poltekkes Kemenkes Jakarta I-Indonesia
}

\begin{abstract}
Background: Reported in Lampung Province, the prevalence of breast cancer cases has increased from $0.02 \%$ in 2010 to $0.7 \%$ in 2013. There were 1.030 cases. Two, Districts with the largest cases of breast cancer are west Lampung (10\%) and Pringsewu (9.8\%).

Purpose: To knowing the effectiveness of a nurse-delivered breast health promotion models on breast cancer early detection behaviors among women of childbearing period age.

Methods: A quantitative study, the population were women of childbearing period age, and samples comprise 120 participant divided in four groups in each group consist 30 participant. 90 participant as intervention group and 30 participant as control group. Independent $t$ test was used in data analysis.

Results: Shows there was no effect of education face to face with the booklet media and education face to face with the detection media cards, but there is a different result with education face to face with the combination of booklet and detection cards $(p=0.004$ mean difference $=0.767)$ on the behavior of early detection of breast cancer.

Conclusion: The health practitioners should provide booklets together with the provision detection card to carry out routinely in preventive efforts. The study also recommends further research on active networking efforts and the efforts of palliative care for those diagnosed with breast cancer.
\end{abstract}

Keywords: Nursing; Health promotion program; Breast cancer; Early detection; Behaviors; Face to face; Booklet media; Detection media cards 
The effectiveness of a nurse-delivered breast health promotion program on breast cancer early detection behaviors

\section{INTRODUCTION}

The case of breast cancer around the world, reported by International Agency for Research on Cancer (IARC) in 2015, is most commonly experienced by women. However, there is a possibility that men can experience it. Usually cancer cells originating from tumor become malignant because the number is uncontrolled and they invade normal tissue or metastasize to other areas of the body (American Cancer Society, 2016). Many factors could increase the risk of this cancer, including alcohol consumption, weight, the use of condoms, and hormonal and physical activities (Meads, Ahmed, \& Riley, 2012; Momenimovahed, \& Salehiniya, 2019; Sun, Zhao, Yang, Xu, Lu, Zhu, \& Zhu, 2017).

Currently, the prevalence of breast cancer in the world has reached 1.6766 million people with a mortality rate of 521.000 deaths (Ghoncheh, Pournamdar, \& Salehiniya, 2016). According to data from the Ministry of Health Republic of Indonesia, number of woman with breast cancer, it is one of causal factors of women's death in Indonesia (Ministry of Health Republic of Indonesia, 2015). Base on basic health research in 2013 states that the prevalence of breast cancer in Indonesia by the end of 2013 amounted to 61.682 (Ministry of Health Republic of Indonesia, 2015). Further, the incidence of breast cancer occurs in 40 / 100.000 cases in which $80 \%$ found at an severe stage. In Lampung Province, the prevalence of breast cancer cases has increased from $0.02 \%$ in 2010 to $0.7 \%$ in 2013 (Ministry of Health Republic of Indonesia, 2015). There were 1,030 cases. Two, Districts with the largest cases of breast cancer are Lampung Barat $(10 \%)$ and Pringsewu (Lampung Provincial Health Office, 2013)

One way to early detect on breast cancer is to perform Breast Self-Examination (BSE). The capablelity in right method to detect $50 \%$ of breast cancer as seen in a mammogram (Farid, Aziz, AlSadat, Jamaludin, \& Dahlui, 2014; Sung, Stamler, Brooks, Kaplan, Huang, Dershaw, \& Comstock, 2016). There are three factors that cause a woman unable to do self examination, such as: lack of knowledge; perceive, she does not a belonging to a risk group; or have not received any information from health professionals (Özdemir, 2014; Al-Rifai, \& Loney, 2017). In fact, BSE is very easy to implementation, practice in monthly by each woman who are menopause period or aged 20 years above on the 7th - 10th day of menstruation (Ministry of Health Republic of Indonesia, 2015; Winardi, \& Novianty, 2018; Husna, \& Fahlevi, 2020).

The changes behavior in early detection is important in order to get detected earlier and reduce the morbidity and mortality. A lot of efforts on preventive and promotive that is carried out by the hospitals and health centers is to provide or give the media such as posters, banners, leaflets, booklets. Heretofore, the public has a poor adequate consultation, with health professionals, finally they have not a significant change in behavior, it was proven when first contact with health professionals, found patient in a severe stage condition.

The research about face-to-face education with booklet media and detection cards is very important in order to get the right methods and media obtained to increase knowledge and motivation that can ultimately change women's behavior in recognizing health problems and the ability to detect breast cancer in earlier.

The preventive of face-to-face education performanced by using media. This study uses the medium of education booklet and detection cards for women of childbearing age with the purpose to increase their knowledge about breast cancer and breast self-examination. Therefore, it can help them to detect any breast abnormality or have a breast examination with the help of health professionals. This study compared some techniques in health promotion program by using of booklets, cards, and combination of booklets and cards in the face-to-face education for early detection in risk breast cancer on women of childbearing age in Pringsewu, LampungIndonesia.

\section{RESEARCH METHODS}

A quasi-experimental design with post test and control group to compare three intervention groups

\footnotetext{
Anita ${ }^{1^{*}}$, Nelly Indrasari', Purwati', Ratna Aryani ${ }^{2}$

'Keperawatan - Poltekkes Kemenkes Tanjungkarang-Bandar Lampung, Indonesia.

${ }^{*}$ Corresponding author. E-mail: anitabustami@yahoo.co.id

${ }^{2}$ Keperawatan - Poltekkes Kemenkes Jakarta l-Indonesia
} 
The effectiveness of a nurse-delivered breast health promotion program on breast cancer early detection behaviors

and one control group. The study began on July to October 2015. This study has obtained the ethical permission from the Nursing Ethics Commission of Tanjungkarang Poltekkes number 147 / EC / KEPTJK / VI / 2015. The intervention by different techniques in each groups; group 1 by education face to face with the media booklet; group 2 by education face to face with the breast cancer early detection cards; group 3 by education face to face with the combination of booklets and early detection cards; and as a control group, group 4 was without any interventions.

The population was women of childbearing age in five hospitals at Pringsewu, Lampung-Indonesia with sample of 120 participants, divided in each four groups and consist of 30 participants. The sampling technique uses non-probability sampling, that is consecutive sampling, with the inclusion criteria; age of 20-45 years, having child and having a family history of breast cancer.

The researcher assisted by one enumerator who served in the polyclinic at each hospital. The enumerator trained according to the steps of the study and evaluated according to the abilities of the researcher. The cancer booklet used in this study made by a team of researchers, consulted to a maternity nursing expertist to follow the guidelines for the management of breast cancer, the cancer management committee of the Ministry of Health of the Republic of Indonesia (2013) and a journal related to breast cancer. The content of the booklet is definition of breast cancer, breast cancer risk factors, signs and symptoms, how to check your own breasts, mammography examination, ultrasonography, surgery, cancer prevention efforts and guidelines for healthy living.

The early breast cancer detection card used in this study was a modification of the Ananto Sidohutomo score, modifications made specifically to detect early breast cancer. Early breast cancer detection cards grouped into three parts: early risk factors, high risk and suspicion of breast cancer. Initial risk factors contain risk factors which are unhealthy lifestyles such as nipple hygiene, smoking habits, alcohol, eating smoky foods, containing preservatives, living in high pollution areas, and obesity, from that obtained 11 questions. High-risk factors include a history of giving birth, breastfeeding for less than six months, taking hormonal pills over five years, exposure to $x$-ray / radiation more than once, a history of breast surgery because of tumors, not treated completely when have breast health problems, diagnosed with breast cancer, family history of cancer and never examined the breasts themselves, from that got 14 questions. Suspect of breast cancer comprises questions related to physical conditions which include lumps in the breast, nipples pulled in, breast skin shrinks and sores, nipples bleed or pus, nipple sores do not heal, lumps quickly enlarge over og $2.5 \mathrm{~cm}$, there were lumps on the shoulder blades and swollen arms, 7 questions obtained.

Face-to-face education with a booklet or card was done twice, and each session took 30 minutes. The timeframe for the first and second sessions is two weeks. Carried out in small number of 6 participants for each group. The booklet illustrated and colored containing the concept of breast cancer and breast self-examination, while the detection cards contains a checklist of "yes I no" lists of initial factors (11 questions), high-risk factors (14 questions) and suspect cancer (7 questions). The contents of the booklet more broadly contain the concept of breast cancer and its management, while the early breast cancer detection card only focuses on the way the respondent assesses risk factors and physically recognizes whether she has a high risk of developing breast cancer. Education face to face with the combination of booklets and cards performed twice in 2 weeks. Each session took 4560 minutes. Participant who have got face to face educational information from the booklet were, given the strength of the early detection of breast cancer independently and practiced breast selfexamination.

Face to face education using a combination of booklets and detection cards done twice, the first session was given booklet material and detection cards, then two weeks later participant were asked to come back and were given an explanation and practice of using the detection cards with the

Anita ${ }^{{ }^{*}}$, Nelly Indrasari', Purwati', Ratna Aryani ${ }^{2}$

'Keperawatan - Poltekkes Kemenkes Tanjungkarang-Bandar Lampung, Indonesia.

${ }^{*}$ Corresponding author. E-mail: anitabustami@yahoo.co.id

${ }^{2}$ Keperawatan - Poltekkes Kemenkes Jakarta l-Indonesia 
The effectiveness of a nurse-delivered breast health promotion program on breast cancer early detection behaviors

guidance of researchers / enumerators. Each face to face session is relatively longer, which is around 45-60 minutes. All behavior changes were assessed after 1 month post-intervention were done individually with the respondent in Obstetric and Gynecologyst polyclinic. The changes behaviour in early detection of breast cancer were measured using a question sheet on the breast self-examination (consist of 6 questions), breast examination to the health (consist of 6 questions). The validity and reliability questionare tests obtained 12 valid and reliable questions with Cronbach's Alfa value of $0.864>$ and $r$ table of 0.361 .

Descriptive statistical analysis waas using statistical distributions and statistics by using independent $T$ tests by carrying out homogeneity and normality tests first.

\section{RESEARCH RESULT}

Table 1. The Normality Test of Participants Characteristics

\begin{tabular}{lccccc}
\hline Characteristic & \multicolumn{3}{c}{ Intervention Groups } & Control Group & P-value \\
\cline { 2 - 4 } & Booklet & Cards & Booklet \& Cards & & \\
\hline Age & 0.787 & 2.243 & 2.536 & 2.094 & 0.108 \\
Education & 1.059 & 0.438 & 2.835 & 2.133 & 0.058 \\
Profession & 0.666 & 1.565 & 2.622 & 1.565 & 0.117 \\
\hline
\end{tabular}

The normality test base on participants' age for all the intervention groups obtained $p$ value greater than 0.05 , it concluded that age data in the intervention and control group distributed normally. Homogeneity test results with one way anova test obtained for all groups are homogeneous with a levene test value of $0.108>p$ value of 0.05 .

Normality test base on participants' education for all the intervention groups obtained $p$ value greater than 0.05 , it concluded that the education data in the intervention and control group distributed normally. Homogeneity test results with one way anova test obtained for all groups are homogeneous with a levene test value of $0.058>$ $p$ value of 0.05 .

Tabel 2. The Frequency Distribution to Behavior on Breast Cancer Early Detection After Intervention

\begin{tabular}{|c|c|c|c|c|}
\hline \multirow{3}{*}{ Technical Models } & \multicolumn{4}{|c|}{ Group } \\
\hline & \multicolumn{2}{|c|}{ Intervention } & \multicolumn{2}{|c|}{ Control } \\
\hline & $\mathbf{n}$ & $\%$ & $\mathrm{n}$ & $\%$ \\
\hline \multicolumn{5}{|l|}{ Education Face to Face \& Booklet } \\
\hline - Excellent performance in early detection of breast cancer & 18 & 60 & 9 & 30 \\
\hline - Poor performance in early detection of breast cancer & 12 & 40 & 21 & 70 \\
\hline \multicolumn{5}{|l|}{ Education Face to Face \& Cards } \\
\hline - Excellent performance in early detection of breast cancer & 14 & 47 & 9 & 30 \\
\hline - Poor performance in early detection of breast cancer & 16 & 53 & 21 & 70 \\
\hline \multicolumn{5}{|l|}{ Education Face to Face With Booklet - Cards } \\
\hline - Excellent performance in early detection of breast cancer & 19 & 63 & 9 & 30 \\
\hline - Poor performance in early detection of breast cancer & 11 & 37 & 21 & 70 \\
\hline
\end{tabular}

Anita ${ }^{*}$, Nelly Indrasari', Purwati', Ratna Aryani ${ }^{2}$

'Keperawatan - Poltekkes Kemenkes Tanjungkarang-Bandar Lampung, Indonesia.

${ }^{*}$ Corresponding author. E-mail: anitabustami@yahoo.co.id

${ }^{2}$ Keperawatan - Poltekkes Kemenkes Jakarta 1-Indonesia 
The effectiveness of a nurse-delivered breast health promotion program on breast cancer early detection behaviors

Based on table 1 knows that from 30 participants by a booklet group, did an excellent performance in early detection of breast cancer of 18 participants $(60 \%)$. Whereas in the control group of 9 participants $(30 \%)$. It shows that the group that got intervention by booklet has more participants did an excellent performance in early detection of breast cancer.

The Group by cards intervention shows did an excellent performance in early detection of breast cancer of 14 participants (47\%). Whereas in the control group of 9 participants (30\%). It shows that the group by cards intervention has more participants did an excellent performance in early detection of breast cancer.

Group by booklet and cards (combination intervention), shows did an excellent performance in early detection of breast cancer of 19 participant (63\%). Whereas in the control of 9 participants $(30 \%)$. It shows that the group that got combination intervention has more participants did an excellent performance in early detection of breast cancer.

Table 3. Influence of Intervention to Behavior on Early Detection of Breast Cancer

\begin{tabular}{lccccc}
\hline The Behavior of Women of Childbearing Age & Mean & SD & SE & P value & N \\
& & & & & \\
\hline The Intervention Group by Booklet & 1.37 & 0.964 & 0.176 & 0.060 & 60 \\
Control Group & 0.90 & 0.923 & 0.168 & & \\
& 1.23 & 0.817 & 0.149 & 0.144 & 60 \\
The Intervention Group by Cards & 0.90 & 0.923 & 0.168 & & \\
Control Group & 1.67 & 0.061 & 0.194 & 0.004 & 60 \\
The Intervention Group by Booklet and Cards & & & & & \\
(Combination Intervention), & 0.90 & 0.923 & 0.168 & & \\
Control Group & & & & & \\
\hline
\end{tabular}

Statistical test results shows that there is no significant relationship between a booklet group intervention and control group with $\mathrm{p}=0.06, \mathrm{Cl}$ $95 \%$ (0.021 - 0.954), or a card group intervention and control group with $\mathrm{p}$-value $=0.144, \mathrm{Cl} 95 \% \quad(-$ $0.117-0.784)$. However, there is a significant effect between by booklets together cards group intervention (combination intervention) and control group with $p$-value $=0.004,95 \% \mathrm{Cl}(0.253-1.281)$ on performance in early detection of breast cancer.

\section{DISCUSSION}

This study shows a significant relationship between the behavior on performance in early detection of breast cancer by face-to-face education intervention with a combination of media booklet and cards when compared to other interventions. The results differ from the results of research conducted by Rantonen et al., (2014) which show that face-to-face education with media booklet have not more effective. Schiller, Schulte-
Körne, Eberle-Sejari, Maier and Allgaier (2014) conducted a study to determine the effectiveness of education by using media booklet (without faceto-face) in teenagers. The results from the study suggest that the booklet can increase knowledge of teenagers against depression, and can help young people to overcome depression if it occurs in their environment. The results also recommend that the more varied a media used (eg education face to face with the media booklet and card detection) the stronger someone's understandings.

The one factor determining the success of the provision of education is the human resources. The educators must can provide education. This research supported by educators who have a minimum education qualification of midwifery or nursing diploma, have the experience of working in obstetrics and clinic for at least 5 years, have knowledge of breast cancer, and have trained by the researchers in the provision of education. Suwankhong's and Liamputtong's research, (2018)

Anita ${ }^{{ }^{*}}$, Nelly Indrasari', Purwati', Ratna Aryani ${ }^{2}$

'Keperawatan - Poltekkes Kemenkes Tanjungkarang-Bandar Lampung, Indonesia.

${ }^{*}$ Corresponding author. E-mail: anitabustami@yahoo.co.id

${ }^{2}$ Keperawatan - Poltekkes Kemenkes Jakarta 1-Indonesia 
The effectiveness of a nurse-delivered breast health promotion program on breast cancer early detection behaviors

on a qualitative study of the difficulty in early detection of breast cancer and screening of Thai migrant women living in Australia, it explains that the factors that inhibit the Thai migrant women from conducting mammography that provided by the Australian government is because the health services and interventions are insensitive to their needs in the socio-cultural context. Likewise, the study done by Wachira, Busakhala, Chite, Naanyu, Kisuya, Otieno, et al (2017) who used the Breast module of a cancer awareness measure (BCAM) in order to increase the knowledge about breast cancer and assess the inhibition factors in screening of breast cancer in Kenya. The results prove that there few women who do breast screening in Kenya, so we need modules that pay attention to their character, beliefs, background, language and culture. Suwankhong and Wachira's research explained that services and interventions including giving the modules were less sensitive to the needs of the woman, background, character, beliefs, language and socio-culture on where the women are. Face to face educational research in this study conducted by combining the provision of booklets and breast cancer early detection cards along with direct counseling with health. Direct communication includes paying attention to the biological, psychological, social and spiritual needs of the participant were done in order to get the comprehensive understanding and routine counseling, so that changes in behavior in the early detection of breast cancer can be realized.

Another research also states there is a significant effect of face-to-face education with a combination of booklet media and cards for behavioral changes in detecting the breast cancer's risk factors in women. The results also support a cross-sectional study conducted by Yuksel, Altunugras, Cavdar, Bozdogan, Gurdan et al (2016) about the assessment of breast cancer's risk and the factors that influenced Turkish women's perceptions of breast cancer risk, the results shows that there is a positive correlation by using the Gail Risk Model (GRM) and Breast Cancer Risk Assessment From (BCRAF) assessments with the result of $p<0.001$, BCRAF and Breast cancer Risk Perception (BCRP) $p$ $<0.001$. In women with high breast risk, there are significant differences between women's perceptions about breast cancer and risk detection behavior for breast cancer.

Kemppainen, Tossavainen, and Turunen (2013) in their study mentioned that nurses have an important role in the success of health promotion that focuses on the prevention of a disease or help to change clients' lifestyle to be more concerned with their own health. However, this role is considered to less clear. It revealed by Harmer (2011) who states that health professionals are effective in helping to raise the awareness of a person attaining a healthy lifestyle.

For the group receiving face-to-face education intervention with a combination of media booklet and card detection, we found that the participant' behavior distribution has a relatively similar result (only a slight difference of $3 \%$ ) when compared to the group receiving only booklet intervention.

\section{CONCLUSION}

Providing health education in order to change a person's behavior for a healthy life. The methods that can use such as face-to-face education with a combination of several media such as booklet and cards are very easy and affordable to apply. This study has proven that by using media has a significant effect on healthy behavioural changes, especially in performance in early detection of breast cancer among women of Childbearing Age.

\section{REFERENCES}

Al-Rifai, R. H., \& Loney, T. (2017). Factors Associated with a Lack of Knowledge of Performing Breast Self-Examination and Unawareness of Cervical Cancer Screening Services: Evidence from the 2015 Egypt Health Issues Survey. Asian Pacific journal of cancer prevention: APJCP, 18(10), 2763.

Anita ${ }^{{ }^{*}}$, Nelly Indrasari', Purwati', Ratna Aryani ${ }^{2}$

'Keperawatan - Poltekkes Kemenkes Tanjungkarang-Bandar Lampung, Indonesia.

${ }^{*}$ Corresponding author. E-mail: anitabustami@yahoo.co.id

${ }^{2}$ Keperawatan - Poltekkes Kemenkes Jakarta 1-Indonesia 
The effectiveness of a nurse-delivered breast health promotion program on breast cancer early detection behaviors

American Cancer Society. (2016). Breast Cancer.

Retrieved June 17, 2016. Retrieved from http://www.cancer.org/acs/groups/cid/document s/webcontent/003090-pdf.pdf

Farid, N. D. N., Aziz, N. A., Al-Sadat, N., Jamaludin, M., \& Dahlui, M. (2014). Clinical breast examination as the recommended breast cancer screening modality in a rural community in Malaysia; what are the factors that could enhance its uptake? PLoS ONE, 9(9), 1-7.

Ghoncheh, M., Pournamdar, Z., \& Salehiniya, H. (2016). Incidence and mortality and epidemiology of breast cancer in the world. Asian Pacific Journal of Cancer Prevention, 17(S3), 43-46.

Harmer, V. (2011). Breast awareness and screening. Nursing Times, 107(25), 21-23.

Husna, A., \& Fahlevi, M. I. (2020). Implementation of SADARI in the early detection of breast cancer in young women high school of west Aceh regency. J-Kesmas: Jurnal Fakultas Kesehatan Masyarakat (The Indonesian Journal of Public Health), 7(1), 51-56.

International Agency for Research on Cancer. (2015). Global Cancer Facts \& Figures. In Atlanta (3rd ed., pp. 1-64). IARC.

Kemppainen, V., Tossavainen, K., \& Turunen, $\mathrm{H}$. (2013). Nurses' roles in health promotion practice: An integrative review. Health Promotion International, 28(4), 490-501.

Lampung Provincial Health Office. (2013). Profil Kesehatan Provinsi Lampung Tahun 2012. Lampung.
Meads, C., Ahmed, I., \& Riley, R. D. (2012). A systematic review of breast cancer incidence risk prediction models with meta-analysis of their performance. Breast Cancer Res Treat, 132(2), 365-377.

Ministry of Health Republic of Indonesia. (2015). Data dan Informasi Kesehatan Situasi Penyakit Kanker. Kemenkes.

Momenimovahed, Z., \& Salehiniya, H. (2019). Epidemiological characteristics of and risk factors for breast cancer in the world. Breast Cancer: Targets and Therapy, 11, 151.

Özdemir, A. (2014). Determination of Breast SelfExamination Knowledge and Breast SelfExamination Practices among Women and Effects of Education on their Knowledge, 7(3).

Rantonen, J., Vehtari, A., Karppinen, J., Luoto, S., Viikari-Juntura, E., Hupli, M., Taimela, S. (2014). Face-to-face information combined with a booklet versus a booklet alone for treatment of mild low-back pain: A randomized controlled trial. Scandinavian Journal of Work, Environment and Health, 40(2), 156-166.

Schiller, Y., Schulte-Körne, G., Eberle-Sejari, R., Maier, B., \& Allgaier, A. K. (2014). Increasing knowledge about depression in adolescents: Effects of an information booklet. Social Psychiatry and Psychiatric Epidemiology, 49(1), 51-58.

Sun, Y. S., Zhao, Z., Yang, Z. N., Xu, F., Lu, H. J., Zhu, Z. Y., \& Zhu, H. P. (2017). Risk factors and preventions of breast cancer. International journal of biological sciences, 13(11), 1387.

Anita $^{1^{*}}$, Nelly Indrasari', Purwati', Ratna Aryani ${ }^{2}$

'Keperawatan - Poltekkes Kemenkes Tanjungkarang-Bandar Lampung, Indonesia.

${ }^{*}$ Corresponding author. E-mail: anitabustami@yahoo.co.id

${ }^{2}$ Keperawatan - Poltekkes Kemenkes Jakarta l-Indonesia 
The effectiveness of a nurse-delivered breast health promotion program on breast cancer early detection behaviors

Sung, J. S., Stamler, S., Brooks, J., Kaplan, J., Huang, T., Dershaw, D. D., \& Comstock, C. E. (2016). Breast cancers detected at screening MR imaging and mammography in patients at high risk: method of detection reflects tumor histopathologic results. Radiology, 280(3), 716722.

Suwankhong D, Liamputtong P. (2018). Early detection of breast and barrier to screening programmes amongst Thai migrant Women in Australia: A qualitative Study. Asian Pacific Journal of Cancer Prevention.DOI: 10.22034/APJCP.2018.19(4). 1089-1097

Wachira, J., Busakhala, A., Chite, F., Naanyu, V., Kisuya, J., Otieno, G., \& Inui, T. (2017). Refining a questionnaire to assess breast cancer knowledge and barriers to screening in Kenya: Psychometric assessment of the BCAM. BMC health services research, 17(1), 110.
Winardi, B., \& Novianty, A. (2018). Knowledge and Attitude Have No Correlation with Implementation of Breast Self Examination (BSE). Folia Medica Indonesiana, 54(3), 218221.

World Health Organization. (2016). Nurse educator core competencies. World Health Organization, 1-30. Retrieved from: https://www.who.int/hrh/nursing_midwifery/nurs e_educator050416.pdf

Yüksel, S., Uğraş, G. A., Cavdar, I., Bozdoğan, A., Gürdal, S. Ö., Akyolcu, N., \& Özmen, V. (2017). A risk assessment comparison of breast cancer and factors affected to risk perception of women in turkey: A cross-sectional study. Iranian journal of public health, 46(3), 308.

Anita $^{1^{*}}$, Nelly Indrasari', Purwati', Ratna Aryani ${ }^{2}$

'Keperawatan - Poltekkes Kemenkes Tanjungkarang-Bandar Lampung, Indonesia.

${ }^{*}$ Corresponding author. E-mail: anitabustami@yahoo.co.id

${ }^{2}$ Keperawatan - Poltekkes Kemenkes Jakarta 1-Indonesia 